\title{
PENGARUH PEMBERIAN JUS TOMAT DAN JERUK NIPIS TERHADAP KADAR GLUKOSA DARAH PADA WANITA DEWASA USIA 40 - 60 TAHUN
}

\section{EFFECT OF TOMATO AND LIME JUICE ON BLOOD GLUCOSE LEVELS IN ADULT WOMEN AGED 40-60 YEARS}

\author{
Wulan Nur Fitriani ${ }^{1}$, Mohammad Jaelani ${ }^{2}$, Arintina Rahayuni ${ }^{3}$ \\ ${ }^{1}$ Mahasiswa Program Studi D-IV Jurusan Gizi Poltekkes Kemenkes Semarang \\ 2,3 Dosen Jurusan Gizi Poltekkes Kemenkes Semarang
}

\begin{abstract}
Background : DM is a chronic disease, not infrequently patients with DM depends on drugs throughout life. Drug consumption brings economic impact besides side effects of course. Therefore it is necessary alternative treatment in preventing the occurrence of DM disease by using vegetables and fruits. Based on the results of Riskesdas 2013, DM prevalence increased from 1.1 percent (2007) to 2.1 percent, while in Semarang there was an increase from 13,112 cases (2013) to 15,464 cases (2014). The highest prevalence in Semarang that is in Kecamatan Pedurungan with working area of Tlogosari Wetan by $8.6 \%$.
\end{abstract}

Objective : To determine the effect of tomato and lime juice on blood glucose levels in adult women aged 40-60 years.

Methods : This research was clinical nutrition research. The type of research was true experiment that used randomized pretest posttest control group design. The sample size is 20 treatments and 18 controls. The test used to determine the difference of blood glucose level between the treatment group and the control group is Independent T-test and to determine the effect of tomato juice and lime juice on blood glucose control with nutrient intake is ANOVA Repeated Measure Test.

Results : Based on statistical tests showed that in subjects with initial blood glucose high category ( $\geq 90 \mathrm{mg} / \mathrm{dl})$ there was more decrease in blood glucose in the treatment group even though statistically not significant ( $p=$ 0 ,354). Subjects with initial blood glucose normal category ( $<90 \mathrm{mg} / \mathrm{dl}$ ) there was decrease in blood glucose even though statistically not significant $(p=0,139)$.

Conclusion : Tomato and lime juice can decrease blood glucose levels in the research subjects, although statistically not significant.

Keywords : consumption of tomato and lime juice, blood glucose level

\section{ABSTRAK}

Latar Belakang : DM tergolong penyakit menahun, tidak jarang pasien penderita DM bergantung pada obat sepanjang hidupnya. Konsumsi obat membawa dampak ekonomi selain efek samping tentunya. Oleh karena itu diperlukan alternatif pengobatan dalam mencegah terjadinya penyakit DM yaitu dengan memanfaatkan sayur dan buah. Berdasarkan hasil Riskesdas 2013, prevalensi DM terjadi peningkatan dari 1,1 persen (2007) menjadi 2,1 persen, sedangkan di Semarang terjadi peningkatan dari 13.112 kasus (2013) menjadi 15.464 kasus (2014). Prevalensi tertinggi di kota Semarang berada di kecamatan Pedurungan dengan wilayah kerja Tlogosari Wetan yaitu sebesar $8,6 \%$.

Tujuan : Untuk mengetahui pengaruh pemberian jus tomat dan jeruk nipis terhadap kadar glukosa darah pada wanita dewasa usia $40-60$ tahun.

Metode : Penelitian ini merupakan penelitian bidang gizi klinik. Jenis penelitian adalah penelitian True Experiment dan menggunakan rancangan penelitian Randomized Pretest Posttest Control Group Design. Jumlah sampel sebanyak 20 perlakuan dan 18 kontrol. Uji yang digunakan untuk mengetahui perbedaan kadar glukosa 
darah antara kelompok perlakuan dan kelompok kontrol adalah Uji Independent T-test dan untuk mengetahui hubungan antara pemberian jus tomat dan jeruk nipis dengan kadar glukosa darah yang dikontrol dengan asupan zat gizi adalahUji ANOVA Repeated Measure.

Hasil : Berdasarkan uji statistik menunjukkan bahwa pada subyek dengan glukosa darah kategori tinggi ( $\geq 90$ $\mathrm{mg} / \mathrm{dl}$ ) ada penurunan glukosa darah lebih banyak pada kelompok perlakuan walaupun berdasarkan statistik tidak signifikan ( $p=0,354)$. Subyek dengan glukosa darah kategori normal $(<90 \mathrm{mg} / \mathrm{dl}$ ) ada penurunan glukosa darah yang tidak signifikan $(p=0,139)$.

Kesimpulan : Pemberian jus tomat dan jeruk nipis dapat menurunkan kadar glukosa darah pada subjek penelitian, walaupun secara statistik tidak signifikan.

Kata kunci: konsumsi jus tomat dan jeruk nipis, kadar glukosa darah

\section{PENDAHULUAN}

Diabetes melitus (DM) merupakan penyakit gangguan metabolik menahun akibat pankreas tidak memproduksi cukup insulin atau tubuh tidak dapat menggunakan insulin yang diproduksi secara efektif, akibatnya terjadi peningkatan konsentrasi glukosa di dalam darah (hiperglikemia). ${ }^{1}$ Berdasarkan hasil Riskesdas 2013, prevalensi DM terjadi peningkatan dari 1,1 persen (2007) menjadi 2,1 persen (Riskesdas, 2013), sedangkan di Semarang terjadi peningkatan dari 13.112 kasus (2013) menjadi 15.464 kasus (2014). ${ }^{2,3}$

DM yang tidak terkontrol sering dikaitkan dengan defisiensi mikronutrien. Penelitian jangka panjang diperlukan untuk menilai keamanan dan manfaat dari kromium, magnesium, dan suplemen antioksidan dan terapi pelengkap lainnya dalam pengelolaan DM tipe $2 .^{4}$

Likopen merupakan salah satu antioksidan, karena kemampuan likopen untuk melawan radikal bebas. ${ }^{5}$ Likopen mempengaruhi resistensi hormon insulin sehingga toleransi tubuh terhadap glukosa menjadi meningkat, dengan meningkatkan konsumsi likopen, maka kelebihan kadar gula darah lebih mudah ditanggulangi. ${ }^{6}$ Mekanisme likopen mencegah penyakit kronik yaitu likopen dapat meningkatkan status likopen dalam tubuh dan bertindak sebagai antioksidan, likopen mengikat oksigen reaktif dan meningkatkan potensi antioksidan atau mengurangi kerusakan oksidatif pada lipid (termasuk lipid membran dan lipoprotein), protein, dan DNA sehingga menurunkan stres oksidatif. ${ }^{7}$ Tomat memiliki kandungan senyawa karotenoid yang bernama likopen. ${ }^{7}$ Likopen dalam 100 gram tomat segar sebanyak 4,6 mg. Kandungan likopen tomat yang diolah menjadi jus meningkat menjadi 9,5 mg/100 gram. ${ }^{8}$

Antioksidan lain yang berperan dalam pengelolaan DM tipe 2 yaitu hesperidin dan naringin. Hesperidin dan naringin adalah flavonoid utama dalam buah jeruk. ${ }^{9}$ Flavonoid sebagai salah satu kelompok senyawa fenolik yang memiliki sifat antioksidatif serta berperan dalam mencegah kerusakan sel dan komponen selularnya oleh radikal bebas reaktif. ${ }^{10}$ Citrus aurantifolia (jeruk nipis) mengandung berbagai nutrisi bio fungsional yaitu flavonoid, karotenoid dan asam askorbat. ${ }^{11}$ Hesperidin dan naringin mempunyai peran penting dalam mencegah perkembangan hiperglikemia, sebagian dengan meningkatkan glikolisis hati dan konsentrasi glikogen dan/atau dengan menurunkan glukoneogenesis hepatik. Hesperidin dan naringin menurunkan aktivitas glucose-6-phosphatase dan phosphoenol pyruvate dengan meningkatkan aktivitas glukokinase hati dan meningkatkan kadar glikogen hati. ${ }^{12}$

Tujuan penelitian untuk mengetahui pengaruh pemberian jus tomat dan jeruk nipis terhadap kadar glukosa darah pada wanita dewasa usia $40-60$ tahun.

\section{METODE PENELITIAN}

Jenis penelitian ini adalah penelitian True Experiment dan menggunakan rancangan penelitian Randomized Repeated Measure Control Group Design. Pada penelitian ini subjek yang memenuhi kategori inklusi dikelompokkan menjadi dua yaitu kelompok perlakuan dan kelompok kontrol. Dalam penelitian kelompok perlakuan diberi jus tomat dan jeruk nipis, sedangkan kelompok kontrol tidak diberi perlakuan.

Lokasi penelitian dilakukan di RW 02 dan RW 09 Kelurahan Pedurungan Tengah Semarang sejak Maret 2017 sampai dengan Mei 2017. Subjek dalam penelitian ini adalah wanita dewasa yang tinggal di wilayah RW 02 dan RW 09 Pedurungan Tengah dengan kategori : usia 40-60 tahun, Indeks Massa Tubuh $>18,5 \mathrm{~kg} / \mathrm{m} 2$, glukosa darah puasa 70 - $234 \mathrm{mg} / \mathrm{dl}$, tidak didiagnosa DM, sehat jasmani dan rohani, tidak mengkonsumsi obat antidiabetes, dan bersedia menjadi responden.pengelompokkan 
subjek penelitian dilakukan dengan cara random. Besar sampel dihitung menggunakan rumus Lemeshow, dengan perbandingan kelompok perlakuan dan kelompok kontrol 1 : 1 maka didapatkan jumlah masing-masing 20 subjek.

Variabel penelitian meliputi variabel bebas yaitu pemberian jus tomat dan jeruk nipis dan variabel terikat yaitu kadar glukosa darah. Instrumen yang akan digunakan terdiri dari formulir identitas, microtoice dan timbangan injak digital untuk mengukur status gizi, glucose meter untuk mengukur kadar glukosa darah, dan formulir food recall 24 jam untuk mengumpulkan data asupan makan. Pelaksanaan penelitian ini selain dilakukan oleh peneliti juga dibantu oleh tiga orang mahasiswi gizi dan satu orang mahasiswi kebidanan.

Untuk mengetahui perbedaan kadar glukosa darah antara kelompok perlakuan dan kelompok kontrol dilakukan analisis bivariat. Uji yang digunakan adalah uji $\mathrm{t}$ test pada tingkat kemaknaan 0,05. Sedangkan untuk mengetahui perbedaan kadar glukosa darah yang dikontrol dengan tingkat asupan energi, protein, lemak, karbohidrat, dan serat, uji yang digunakan uji Repeated Measure ANOVA pada tingkat kemaknaan 0,05 .

\section{HASIL DAN PEMBAHASAN}

Penelitian ini dilakukan di RW 02 dan RW 09 Kelurahan Pedurungan Tengah Semarang terhadap wanita dewasa yang berusia 40-60 tahun sejak Maret 2017 sampai dengan Mei 2017. Jumlah subjek yang diteliti sebanyak 38 orang yang terdiri dari kelompok perlakuan sebanyak 20 orang dan kelompok kontrol sebanyak 18 orang. Pada kelompok kontrol ada dua orang yang di keluarkan sehingga jumlahnya menjadi 18 orang karena 1 orang mengkonsumsi obat antidiabetes dan 1 orang lagi tidak dapat ditemui sehingga tidak dapat diukur glukosa darahnya.

\section{Karakteristik Subjek}

Tabel 1. menunjukkan bahwa umur subjek pada kelompok perlakuan rata-rata adalah 50 tahun dengan umur termuda 42 tahun dan umur tertua 60 tahun, sedangkan umur pada kelompok kontrol rata-rata 51 tahun dengan umur termuda 40 tahun dan umur tertua 58 tahun. Wanita usia 40 tahun ke atas memasuki masa perimenopause atau mendekati menopause biasanya terjadi pada usia 45 - 55 tahun. Estrogen dan progesteron pada usia tersebut biasanya naik turun tidak teratur, sehingga glukosa darah menjadi tidak menentu. Ovarium membentuk sel telur lebih sedikit. Estrogen berkurang dan resistensi insulin mulai timbul sehingga glukosa darah meningkat, terkadang terjadi penurunan progesteron yang membuat sel lebih sensitif terhadap insulin sehingga glukosa darah menurun. ${ }^{13}$

Tabel 2. menunjukkan sebagian besar subjek termasuk dalam kategori obesitas 1 dengan persentase lebih banyak pada kelompok perlakuan sebesar 35\% dan kelompok kontrol 27,8\%. Kategori normal pada kelompok perlakuan lebih banyak (20\%) dibanding kelompok kontrol (11,1\%). Kategori overweight pada kelompok perlakuan lebih sedikit (20\%) dibanding kelompok kontrol $(33,3 \%)$. Kategori obesitas 2 pada kelompok kontrol lebih banyak $(27,8 \%)$ dibanding kelompok perlakuan (25\%). Overweight dan Obesitas merupakan salah satu faktor risiko terjadinya DM. Obesitas dapat memicu perubahan pada metabolisme tubuh yang menyebabkan jaringan adiposa (lemak) melepaskan sejumlah asam lemak, gliserol, hormon, sitokin pro-inflamasi dan faktor lain yang terlibat dalam pengembangan resistensi insulin. Ketika resistensi insulin disertai dengan disfungsi sel beta pulau pankreas (sel yang melepaskan insulin), hal itu menyebabkan kegagalan mengendalikan kadar glukosa darah. ${ }^{14}$

Tabel 3. menunjukkan bahwa sebagian besar subjek tamat SD/MI dengan persentase lebih banyak pada kelompok perlakuan sebesar $40 \%$ dan kelompok kontrol $27,8 \%$. Tidak tamat SD pada kelompok perlakuan lebih sedikit (15\%) dibanding kelompok kontrol (22,2\%). Tamat SMP/MTS pada kelompok perlakuan lebih sedikit (15\%) dibanding kelompok kontrol (22,2\%). Tamat SMA/sederajat pada kelompok perlakuan lebih sedikit (25\%) dibanding kelompok kontrol (27,8\%).Tamat D1/D2/D3 pada kelompok perlakuan yaitu 5\%, sedangkan kelompok kontrol $0 \%$ dibanding kelompok perlakuan (25\%).

Tabel 4. menunjukkan bahwa kadar glukosa darah subjek sebelum penelitian pada kelompok perlakuan rata-rata adalah $102,40 \mathrm{mg} / \mathrm{dl}$ dengan kadar terendah $75 \mathrm{mg} / \mathrm{dl}$ dan kadar tertinggi $234 \mathrm{mg} / \mathrm{dl}$, sedangkan kadar glukosa darah subjek pada kelompok kontrol rata-rata adalah 95,61 mg/dl dengan kadar terendah $78 \mathrm{mg} / \mathrm{dl}$ dan kadar tertinggi $131 \mathrm{mg} / \mathrm{dl}$.

Tabel 5. menunjukkan bahwa kadar glukosa darah sebelum penelitian sebagian besar subjek termasuk dalam kategori normal dengan persentase lebih banyak pada kelompok perlakuan sebesar 55\% dan kelompok kontrol 50\%. Kategori kadar glukosa darah tinggi pada kelompok 
perlakuan sebesar $45 \%$, sedangkan pada kelompok kontrol sebesar $50 \%$.

Tabel 1. Karakteristik Subjek Menurut Umur

\begin{tabular}{lcccccccc}
\hline & \multicolumn{8}{c}{ Kelompok } \\
\cline { 2 - 9 } Variabel & \multicolumn{3}{c}{ Perlakuan (n=20) } & \multicolumn{5}{c}{ Kontrol (n=18) } \\
\cline { 2 - 9 } & Rerata & SD & Min & Max & Rerata & SD & Min & Max \\
\hline $\begin{array}{l}\text { Umur } \\
\text { (tahun) }\end{array}$ & 50 & 5,473 & 42 & 60 & 51 & 5,247 & 40 & 58 \\
\hline
\end{tabular}

Tabel 2. Karakteristik Subjek Menurut Status Gizi

\begin{tabular}{ccccc}
\hline \multirow{2}{*}{$\begin{array}{c}\text { Kategori } \\
(\%)\end{array}$} & \multicolumn{3}{c}{ Kelompok } \\
\cline { 2 - 5 } & $\mathrm{n}$ & $\%$ & $\mathrm{n}$ & $\%$ \\
\hline Normal & 4 & 20 & 2 & 11,1 \\
Overweight & 4 & 20 & 6 & 33,3 \\
Obesitas 1 & 7 & 35 & 5 & 27,8 \\
Obesitas 2 & 5 & 25 & 5 & 27,8 \\
\hline \multicolumn{1}{c}{ Total } & 20 & 100 & 18 & 100 \\
\hline
\end{tabular}

Tabel 3. Karakteristik Subjek Menurut Pendidikan

\begin{tabular}{lcccc}
\hline \multirow{2}{*}{$\begin{array}{c}\text { Kategori } \\
\text { (\%) }\end{array}$} & \multicolumn{4}{c}{ Kelompok } \\
\cline { 2 - 5 } & $\mathrm{n}$ & $\%$ & $\mathrm{n}$ & $\%$ \\
\hline Tidak tamat SD & 3 & 15 & 4 & 22,2 \\
SD/MI & 8 & 40 & 5 & 27,8 \\
SMP/MTS & 3 & 15 & 4 & 22,2 \\
SMA/sederajat & 5 & 25 & 5 & 27,8 \\
D1/D2/D3 & 1 & 5 & 0 & 0 \\
\hline \multicolumn{1}{c}{ Total } & 20 & 100 & 18 & 100 \\
\hline
\end{tabular}

Tabel 4. Karakteristik Kadar Glukosa Darah Subjek Sebelum Penelitian Pada Kelompok Perlakuan dan Kelompok Kontrol

\begin{tabular}{lllllllll}
\hline \multirow{2}{*}{ Variabel } & \multicolumn{9}{c}{ Kelompok } \\
\cline { 2 - 9 } & \multicolumn{3}{c}{ Perlakuan $(\mathrm{n}=20)$} & \multicolumn{5}{c}{ Kontrol $(\mathrm{n}=18)$} \\
\cline { 2 - 8 } & Rerata & SD & Min & Max & Rerata & SD & Min & Max \\
\hline $\begin{array}{l}\text { Kadar } \\
\text { Glukosa }\end{array}$ & 102,40 & 38,480 & 75 & 234 & 95,61 & 16,191 & 78 & 131 \\
$\begin{array}{l}\text { Darah } \\
\text { (mg/dl) }\end{array}$ & & & & & & & & \\
\hline
\end{tabular}

Tabel 5. Karakteristik Subjek Menurut Kategori Kadar Glukosa Darah

\begin{tabular}{ccccc}
\hline \multirow{2}{*}{$\begin{array}{c}\text { Kategori } \\
(\%)\end{array}$} & \multicolumn{3}{c}{ Kelompok } \\
\cline { 2 - 5 } & $\mathrm{n}$ & $\%$ & $\mathrm{n}$ & $\%$ \\
\hline Normal $(<90 \mathrm{mg} / \mathrm{dl})$ & 11 & 55 & 9 & 50 \\
Tinggi $(\geq 90 \mathrm{mg} / \mathrm{dl})$ & 9 & 45 & 9 & 50 \\
Total & 20 & 100 & 18 & 100 \\
\hline
\end{tabular}

\section{Asupan Zat Gizi}

Tabel 6 menunjukkan bahwa sebagian besar asupan energi subjek sangat kurang dengan persentase lebih banyak pada kelompok perlakuan sebesar $85 \%$ dan kelompok kontrol $72,2 \%$. Asupan protein subjek sangat kurang dengan persentase lebih banyak pada kelompok perlakuan sebesar $75 \%$ dan kelompok kontrol 72,2\%. Asupan lemak subjek sangat kurang dengan persentase lebih banyak pada kelompok kontrol sebesar $61,1 \%$ dan kelompok perlakuan 50\%. Protein, lemak, serta fruktosa dan galaktosa yang diserap dihasilkan dari pencernaan sukrosa dan laktosa, masing-masing memiliki sedikit pengaruh pada konsentrasi glukosa darah. ${ }^{15}$ Peran asupan protein dalam pengelolaan hiperglikemia hanya dilihat dari jumlah glukosa yang dihasilkan berasal dari asam amino melalui proses glukoneogenesis. ${ }^{16}$ Asupan karbohidrat subjek sangat kurang dengan persentase lebih banyak pada kelompok perlakuan sebesar $85 \%$ dan kelompok kontrol 72,2\%. Karbohidrat terbagi menjadi dua yaitu sederhana (gula) atau kompleks (pati). Karbohidrat sederhana (monosakarida dan disakarida) lebih banyak meningkatkan konsentrasi glukosa darah daripada karbohidrat kompleks yang kaya serat. ${ }^{17}$ Asupan serat subjek kurang dengan persentase yang sama pada kelompok perlakuan dan kelompok kontrol sebesar $100 \%$. Kandungan serat yang tinggi dalam makanan akan mempunyai indeks glikemik yang rendah sehingga dapat memperpanjang pengosongan lambung yang dapat menurunkan sekresi insulin dan kolesterol total dalam tubuh. ${ }^{18}$ Data secara lengkap dapat dilihat pada tabel 6 .

Tabel 6. Karakteristik Subjek Menurut Kategori Asupan Energi, Protein, Lemak, Karbohidrat, dan Serat Terhadap Kecukupan

\begin{tabular}{lcccc}
\hline \multirow{2}{*}{$\begin{array}{c}\text { Kategori } \\
\text { (\%) }\end{array}$} & \multicolumn{4}{c}{ Kelompok } \\
\cline { 2 - 5 } & $\mathrm{n}$ & $\%$ & $\mathrm{n}$ & $\%$ \\
\hline Asupan Energi & & & & \\
$\quad$ Sangat kurang & 17 & 85 & 13 & 72,2 \\
$\quad$ Kurang & 3 & 15 & 5 & 27,8 \\
\hline Asupan Protein & & & & \\
$\quad$ Sangat kurang & 15 & 75 & 13 & 72,2 \\
$\quad$ Kurang & 5 & 25 & 5 & 27,8 \\
\hline Asupan Lemak & 10 & 50 & 11 & 61,1 \\
$\quad$ Sangat kurang & 7 & 35 & 3 & 16,7 \\
$\quad$ Kurang & 2 & 10 & 4 & 22,2 \\
$\quad$ Normal & 1 & 5 & 0 & 0 \\
$\quad$ Lebih & 17 & 85 & 13 & 72,2 \\
\hline Asupan Karbohidrat & 3 & 15 & 5 & 27,8 \\
$\quad$ Sangat kurang & & & & \\
$\quad$ Kurang & & 100 & 18 & 100 \\
\hline Asupan Serat & & & & \\
Kurang &
\end{tabular}

Tingkat Kepatuhan Konsumsi Jus Tomat dan Jeruk Nipis 
Tabel 7 menunjukkan bahwa pada setiap minggunya mengalami penurunan. Rerata kepatuhan konsumsi jus tomat dan jeruk nipis pada minggu pertama yaitu sebesar $97,5 \%$, minggu kedua sebesar $97,357 \%$, minggu ketiga sebesar $96,964 \%$.

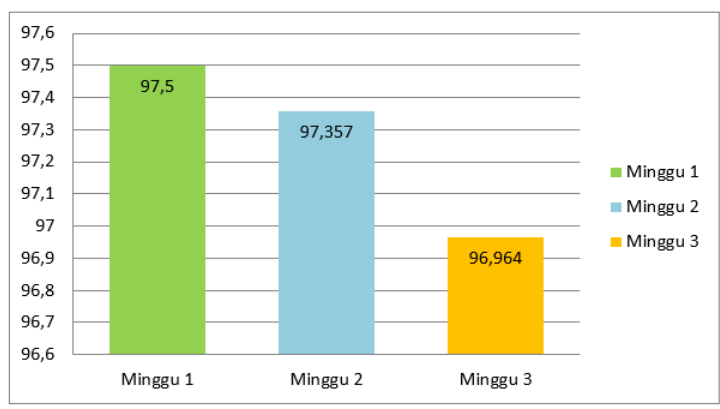

Gambar 1. Distribusi Sampel Menurut Tingkat Konsumsi Subjek Terhadap Jus Tomat dan Jeruk Nipis

Pengaruh Pemberian Jus Tomat dan Jeruk Nipis Terhadap Kadar Glukosa Darah

Berdasarkan hasil analisa bivariat (tabel 7) secara statistik menunjukkan tidak ada perbedaan yang signifikan selisih kadar glukosa darah antara kelompok perlakuan dan kelompok kontrol pada minggu pertama, kedua, dan ketiga $(p>0,05)$.

Tabel 7. Perbedan Kadar Glukosa Darah Subyek Setiap Minggu Selama Penelitian Pada Kelompok Perlakuan dan Kelompok Kontrol

\begin{tabular}{|c|c|c|c|c|c|}
\hline \multirow{3}{*}{$\begin{array}{c}\text { Selisih Kadar Glukosa } \\
\text { Darah }\end{array}$} & \multicolumn{4}{|c|}{ Kelompok } & \multirow{3}{*}{ Nilai $p$} \\
\hline & \multicolumn{2}{|c|}{ Perlakuan $(n=20)$} & \multicolumn{2}{|c|}{ Kontrol $(n=18)$} & \\
\hline & Rerata & SD & Rerata & SD & \\
\hline Minggu 1 & $+4,85$ & 18,905 & +3 & 13,491 & $0,682^{1}$ \\
\hline Minggu 2 & $+7,15$ & 20,843 & $+2,44$ & 15,678 & $0,188^{1}$ \\
\hline Minggu 3 & $-5,95$ & 21,736 & $-9,33$ & 14,175 & $0,578^{2}$ \\
\hline
\end{tabular}

Dengan membedakan kelompok berdasarkan kategori kadar glukosa darah awal normal (<90 mg/dl) dan tinggi (> $90 \mathrm{mg} / \mathrm{dl}$ ), dilakukan analisis tentang perbedaan kadar glukosa darah antara sebelum dan sesudah perlakuan menunjukkan ada perbedaan yang tidak signifikan pada subjek kelompok normal (<90 mg/dl). Perbedaan kadar glukosa darah pada kelompok perlakuan dan kelompok kontrol berdasarkan kategori normal dapat dilihat pada tabel 8.

Tabel 8. Perbedaan Kadar Glukosa Darah Pada Kelompok Perlakuan dan Kelompok Kontrol
Berdasarkan Kategori Kadar Glukosa Darah Awal Normal (<90 mg/dl)

\begin{tabular}{|c|c|c|c|c|c|}
\hline \multirow{3}{*}{$\begin{array}{c}\text { Selisih Kadar Glukosa } \\
\text { Darah }\end{array}$} & \multicolumn{4}{|c|}{ Kelompok } & \multirow{3}{*}{ Nilai $p$} \\
\hline & \multicolumn{2}{|c|}{ Perlakuan $(n=11)$} & \multicolumn{2}{|c|}{ Kontrol $(n=9)$} & \\
\hline & Rerata & SD & Rerata & SD & \\
\hline Minggu 1 & $+13,91$ & 17,432 & $+5,67$ & 9,46 & $0,468^{1}$ \\
\hline Minggu 2 & $+15,64$ & 12,683 & $+4,22$ & 7,546 & $0,029^{2}$ \\
\hline Minggu 3 & $+4,91$ & 12,169 & $-2,56$ & 8,11 & $0,133^{2}$ \\
\hline
\end{tabular}

Uji Mutivariat dengan menggunakan Uji ANOVA Repeated Measure dapat dilihat pada tabel 9.

Tabel 9. Uji Multivariat ANOVA Repeated Measure Kadar Glukosa Darah Kategori Normal (<90 mg/dl)

\begin{tabular}{ll}
\hline \multicolumn{1}{c}{ Variabel } & Nilai $\mathrm{p}$ \\
\hline Persen_Kec_Energi & 0,319 \\
Persen_Kec_Protein & 0,292 \\
Persen_Kec_Lemak & 0,364 \\
Persen_Kec_KH & 0,303 \\
Asupan_Serat & 0,684 \\
Kelompok & 0,139 \\
\hline
\end{tabular}

Perbedaan kadar glukosa darah pada kelompok perlakuan dan kelompok kontrol berdasarkan kategori normal $(<90 \mathrm{mg} / \mathrm{dl}$ ) dapat dilihat pada Gambar 2.

Estimated Marginal Means of MEASURE_1

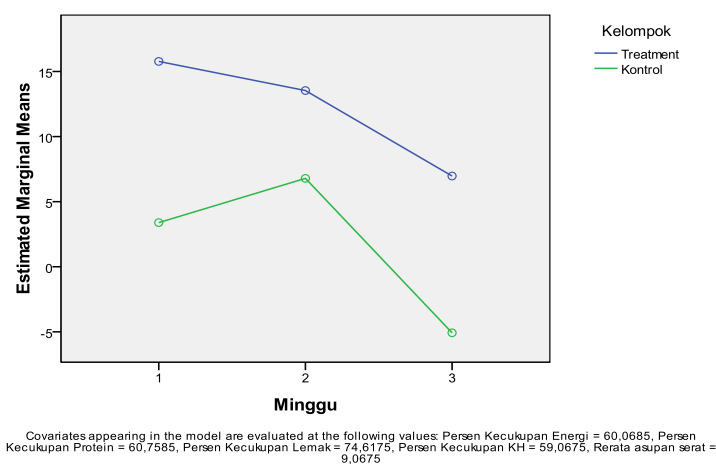

Gambar 2. Perbedaan Kadar Glukosa Darah Setiap Minggu Selama Penelitian Pada Kelompok Perlakuan dan Kelompok Kontrol Berdasarkan Kategori Kadar Glukosa Darah Awal Normal (<90 $\mathrm{mg} / \mathrm{dl})$

Hasil analisis menggunakan uji ANOVA Repeated Measure menunjukkan ada perbedaan yang tidak signifikan $(p=0,139)$ antara kadar glukosa darah pada kelompok perlakuan dan kelompok kontrol, sedangkan tingkat kecukupan energi, protein, lemak, karbohidrat, dan serat tidak berpengaruh terhadap perubahan kadar glukosa darah. Jika dilihat dari grafik gambar 1 terlihat bahwa terjadi kenaikan yang lebih banyak pada 
kelompok perlakuan di minggu pertama, sedangkan kelompok kontrol mengalami kenaikan yang lebih sedikit di minggu pertama. Pada minggu kedua kelompok kontrol mengalami kenaikan, sedangkan kelompok perlakuan mengalami penurunan. Pada minggu ketiga kelompok perlakuan dan kelompok kontrol sama-sama terjadi penurunan, tetapi penurunan yang signifikan terjadi pada kelompok kontrol. Hal ini mungkin terjadi karena subyek yang dijadikan kelompok perlakuan dan kelompok kontrol memiliki kadar glukosa normal atau tidak mengalami gangguan resistensi insulin, seperti penelitian Djaya, dkk (2011) tentang pengaruh ekstrak kayu manis terhadap kadar glukosa darah tikus menyatakan bahwa ektrak kayu manis tidak signifikan menurunkan kadar gula darah pada tikus percobaan yang tidak mengalami gangguan resistensi insulin seperti penderita DM, karena ekstrak kayu manis tidak mempengaruhi reseptor insulin yang normal. ${ }^{19}$ Faktor kemungkinan lain yang berpengaruh terhadap kadar glukosa darah adalah aktifitas fisik dan olahraga yang tidak diperhitungkan dalam penelitian ini. Ada beberapa hal yang menyebabkan gula darah naik, yaitu kurang berolah raga, bertambahnya jumlah makanan yang dikonsumsi, meningkatnya stress dan faktor emosi, pertambahan berat badan dan usia, serta dampak perawatan dari obat, seperti steroid. ${ }^{20}$

Perbedaan kadar glukosa darah pada kelompok perlakuan dan kelompok kontrol berdasarkan kategori tinggi ( $\geq 90 \mathrm{mg} / \mathrm{dl}$ ) dapat dilihat pada Tabel 10.

Tabel 10. Perbedaan Kadar Glukosa Darah Pada Kelompok Perlakuan dan Kelompok Kontrol Berdasarkan Kategori Kadar Glukosa Darah Awal Tinggi ( $\geq 90 \mathrm{mg} / \mathrm{dl}$ )

\begin{tabular}{|c|c|c|c|c|c|}
\hline \multirow{3}{*}{$\begin{array}{c}\text { Selisih Kadar Glukosa } \\
\text { Darah }\end{array}$} & \multicolumn{4}{|c|}{ Kelompok } & \multirow{3}{*}{ Nilai $p$} \\
\hline & \multicolumn{2}{|c|}{ Perlakuan $(n=9)$} & \multicolumn{2}{|c|}{ Kontrol $(n=9)$} & \\
\hline & Rerata & SD & Rerata & SD & \\
\hline Minggu 1 & $-6,22$ & 14,771 & $+0,33$ & 16,771 & $0,658^{1}$ \\
\hline Minggu 2 & $-3,22$ & 24,712 & $+0,67$ & 21,407 & $0,726^{2}$ \\
\hline Minggu 3 & $-19,22$ & 24,014 & $-16,11$ & 16,058 & $0,751^{2}$ \\
\hline
\end{tabular}

Uji Mutivariat dengan menggunakan Uji ANOVA Repeated Measure dapat dilihat pada tabel 11.

Tabel 11. Uji Multivariat ANOVA Repeated Measure Kadar Glukosa Darah Kategori Tinggi ( $\geq$ $90 \mathrm{mg} / \mathrm{dl}$ )

\begin{tabular}{lc}
\hline \multicolumn{1}{c}{ Variabel } & Nilai p \\
\hline Persen_Kec_Energi & 0,138 \\
Persen_Kec_Protein & 0,129 \\
Persen_Kec_Lemak & 0,137 \\
Persen_Kec_KH & 0,136 \\
Persen_Kec_Serat & 0,168 \\
Kelompok & 0,354 \\
\hline
\end{tabular}

Perbedaan Kadar Glukosa Darah Pada Kelompok Perlakuan dan Kelompok Kontrol Berdasarkan Kategori Tinggi ( $\geq 90 \mathrm{mg} / \mathrm{dl}$ ) dapat dilihat pada Gambar 3.

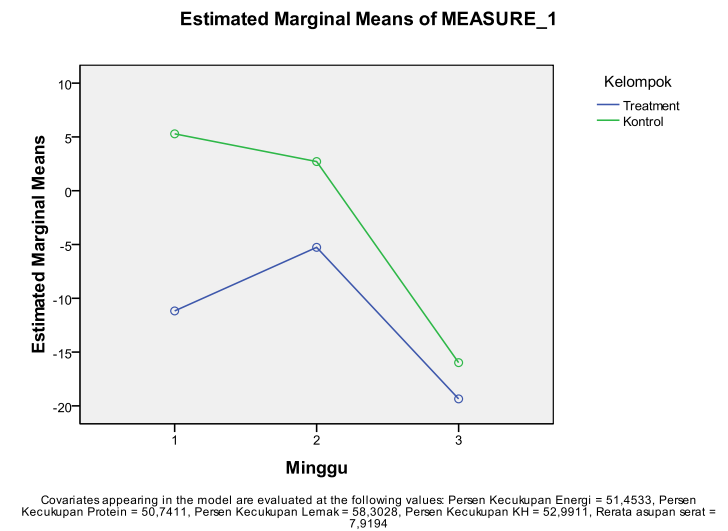

Gambar 3. Perbedaan Kadar Glukosa Darah Setiap Minggu Selama Penelitian Pada Kelompok Perlakuan dan Kelompok Kontrol Berdasarkan Kategori Kadar Glukosa Darah Awal Tinggi ( $\geq 90$ $\mathrm{mg} / \mathrm{dl}$ )

Hasil analisis menggunakan uji ANOVA Repeated Measure menunjukkan ada perbedaan yang tidak signifikan $(p=0,354)$ antara kadar glukosa darah pada kelompok perlakuan dan kelompok kontrol, sedangkan tingkat kecukupan energi, protein, lemak, karbohidrat, dan serat tidak berpengaruh terhadap perubahan kadar glukosa darah. Jika dilihat dari grafik gambar 2 terlihat bahwa terjadi penurunan yang lebih banyak pada kelompok perlakuan di minggu pertama, sedangkan kelompok kontrol mengalami kenaikan. Minggu kedua kelompok perlakuan mengalami kenaikan, sedangkan kelompok kontrol mengalami penurunan yang tidak signifikan. Minggu ketiga kelompok perlakuan dan kelompok kontrol samasama mengalami penurunan, tetapi penurunan yang lebih banyak terjadi pada kelompok perlakuan.

Perbedaan kadar glukosa yang tidak signifikan antara kelompok perlakuan dan kelompok mungkin dikarenakan oleh faktor perbedaan kandungan likopen pada tomat yang ikut berpengaruh terhadap kadar glukosa darah, seperti penelitian Chairunnisa (2012) tentang pengaruh jumlah pasta tomat terhadap penurunan kadar gula darah pada mencit diabetes menyatakan 
bahwa pemberian pasta tomat yang paling efektif untuk menurunkan kadar gula darah adalah $62 \mathrm{mg}$ pasta tomat $=40 \mathrm{mg}$ likopen dengan persentase penurunan kadar gula darah mencapai $75,60 \% .^{21}$ Perbedaan hasil penelitian ini dengan hasil penelitian Chairunnisa, kemungkinan dikarenakan oleh faktor perbedaan kandungan likopen pada tomat, karena pada penelitian ini menggunakan jus dengan tomat yang memiliki kandungan likopen 17,1 mg. Hasil penelitian ini berbeda dengan penelitian Astuti dan Murwani tahun 2013 menunjukkan bahwa pemberian jus tomat $200 \mathrm{ml}$ dengan jumlah tomat yang digunakan sebanyak 180 gram dapat menurunkan kadar glukosa darah puasa sebesar $9,00 \mathrm{mg} / \mathrm{dl}(7,64 \%)$ pada prediabetes selama 3 minggu. ${ }^{22}$ Hasil penelitian yang dilakukan oleh Karimi dan Nasab menunjukkan bahwa pemberian jus jeruk nipis pada tikus DM sebanyak 1,1 cc dengan konsentrasi $50 \%$ selama 21 hari secara signifikan $(p<0,05)$ menurunkan kadar glukosa darah tapi efek menguntungkan ini pada hiperglikemia tikus DM memiliki efek jangka pendek. ${ }^{23}$ Pada kelompok kontrol yang juga mengalami penurunan kadar glukosa darah mungkin disebabkan oleh faktor asupan makannya yang mulai dikontrol sendiri dan dijaga oleh masingmasing individu tersebut. Faktor kemungkinan lain adalah lama puasa sebelum pengecekan kadar glukosa darah karena dalam penelitian ini lama puasa masing-masing responden tidak selalu sesuai dengan waktu yang ditentukan yaitu 8-10 jam, ada yang lebih atau kurang dari waktu tersebut. Jika tidak berpuasa sesuai dengan waktu yang ditentukan, hasil pemeriksaan akan memberikan hasil yang tidak akurat karena masih dipengaruhi oleh makanan. ${ }^{24}$ Kemungkinan lainnya yang berpengaruh terhadap kadar glukosa darah adalah aktifitas fisik dan olahraga yang tidak diperhitungkan dalam penelitian ini. Ada beberapa hal yang menyebabkan gula darah naik, yaitu kurang berolah raga, bertambahnya jumlah makanan yang dikonsumsi, meningkatnya stress dan faktor emosi, pertambahan berat badan dan usia, serta dampak perawatan dari obat, seperti steroid. ${ }^{20}$

\section{Kesimpulan dan Saran Kesimpulan}

Dari penelitian ini dapat diambil kesimpulan sebagai berikut:

1. Tingkat kepatuhan konsumsi terhadap jus tomat dan jeruk nipis pada kelompok perlakuan menunjukkan bahwa pada setiap minggunya mengalami penurunan. Rerata kepatuhan konsumsi jus tomat dan jeruk nipis pada minggu pertama yaitu sebesar 97,5\%, minggu kedua sebesar $97,357 \%$, minggu ketiga sebesar $96,964 \%$.

2. Pada subjek dengan kadar glukosa darah kategori tinggi ( $\geq 90 \mathrm{mg} / \mathrm{dl}$ ), ada perbedaan glukosa darah yang tidak signifikan antara kelompok perlakuan dan kelompok kontrol $(p>0,05)$, tetapi kelompok perlakuan mengalami penurunan yang lebih banyak dibandingkan kelompok kontrol.

3. Pada subjek dengan kadar glukosa darah kategori normal (<90 mg/dl), ada perbedaan glukosa darah yang tidak signifikan antara kelompok perlakuan dan kelompok kontrol ( $p>0,05)$.

4. Pemberian jus tomat dan jeruk nipis dapat menurunkan kadar glukosa darah pada subjek penelitian, walaupun secara statistik tidak signifikan.

\section{Saran}

Berdasarkan hasil penelitian di atas, maka saran yang diberikan adalah sebagai berikut :

1. Jus tomat dan jeruk nipis dapat dikonsumsi setelah makan.

2. Perlu penelitian lebih lanjut untuk melakukan pengambilan data aktifitas fisik dan olah raga karena aktifitas fisik dan olahraga memiliki pengaruh terhadap kadar glukosa darah.

3. Perlu penelitian lebih lanjut untuk menggunakan sampel dengan kriteria kadar glukosa darah yang tinggi ( $\leq 90 \mathrm{mg} / \mathrm{dl}$ ).

\section{DAFTAR PUSTAKA}

1. Kementerian Kesehatan RI. InfoDATIN Pusat Data dan Informasi Kementerian Kesehatan RI. Jakarta: Kementerian Kesehatan RI, 2014, hal. 1-7.

2. Balitbang Kemenkes RI. Riset Kesehatan Dasar (RISKESDAS). Jakarta: Balitbang Kemenkes RI, 2013.

3. Dinas Kesehatan Kota Semarang. Profil Kesehatan Kota Semarang Tahun 2014. Semarang: Dinas Kesehatan Kota Semarang, 2015, hal. 56.

4. America Diabetes Association. Nutrition Recommendations and Interventions for Diabetes. Diabetes Care, Volume 31 : 2008, p.567.

5. Sayuti, K. dan Yenrina, R. Antioksidan, Alami dan Sintetik. Padang: Andalas University Press, 2015, hal. 12-14. 
6. Astawan, M. dan Kasih, A. L. Khasiat WarnaWarni Makanan. Jakarta: PT Gramedia Pustaka Utama, 2008., hal. 68.

7. Agarwal, S. dan Rao, A. V. Tomato Lycopene and Its Role in Human Health and Chronic Disease. Canadian Medical Association Journal, 2000, 163(6): p.739-44.

8. Kailaku, S. I, Dewandari, K. T. dan Sunarmani. Potensi Likopen Dalam Tomat Untuk Kesehatan. Buletin Teknologi Pascapanen Pertanian, Vol. 3, 2007, p. 50-58.

9. Caballero, B, Finglas, P. M. dan Toldra, F. (Eds.). Encyclopedia of Food and Health. Kidlington, Oxford ; Waltham, MA : Academic Press is an imprint of Elsevier, Volume 1, 2016, p.140.

10. Redha, A. Flavonoid: Struktur, Sifat Antioksidatif dan Peranannya Dalam Sistem Biologis. Jurnal Belian, Vol. 9 No. 2, 2010, hal. $196-202$.

11. Boshtam, M, Moshtaghian, J, Naderi, G, Asgary, S, dan Nayen, $H$. Antioxidant effects of Citrus aurantifolia (Ch ristm) juice and peel extract on LDL oxidation. Journal of Research in Medical Sciences, 2011, 16(7), 951-955.

12. Jung, Un Ju, Lee, Mi-Kyung, Jeong, Kyu-Shik, dan Choi, Myung-Sook. The Hypoglycemic Effects of Hesperidin and Naringin Are Partly Mediated by Hepatic Glucose-Regulating Enzymes in C57BL/KsJ-db/db Mice. The Journal of Nutrition, 2004, p.2499-2503.

13. Tandra, H. Segala Sesuatu yang Harus Anda Ketahui Tentang Diabetes. Jakarta: PT Gramedia Pustaka Utama, 2007, hal. 204-261.

14. Kahn, Steven E., Hull, Rebecca L., and Utzschneider, Kristina M.. Mechanisms Linking Obesity to Insulin Resistance and Type 2 Diabetes. Nature, Vol. 444, 2006, p.840-846

15. Gannon, Mary C and Nutall, Frank Q. Effect of a High-Protein, Low-Carbohydrate Diet on Blood Glucose Control in People With Type 2 Diabetes. Diabetes Care, Vol. 53, 2004, p.2375-2382

16. Gannon, Mary C.,Nuttal, Frank Q., Saeed, Asad, Jordan, Kelly, and Hoover, Heidi. An
Increase in Dietary Protein Improves The Blood Glucose Response in Persons with Type 2 Diabetes. The American Journal of Clinical Nutrition,78: 2003, 734-741.

17. Shils, Maurice E., Shike, Moshe, Ross, A. Catharine, Caballero, Benjamin, dan Cousins, Robert J.. Modern Nutrition in Health and Disease: 10th (tenth) Edition. Philadelphia: Lippincott, 2006, p. 1051.

18. Witasari, Ucik, Rahmawaty, Setyaningrum, dan Zulaekah, Siti. Hubungan Tingkat Pengetahuan, Asupan Karbohidrat dan Serat dengan Pengendalian Kadar Glukosa Darah pada Penderita Diabetes Mellitus Tipe2. Jurnal Penelitian Sains dan Teknologi, Vol. 10 No 2, 2009, hal. 130-138

19. Djaya, Nanny, Hidayat, Jenny, Sidharta, Veronika M., Puspadewi, natalia, Margaret, Ayly, dan Dara, Maria. Pengaruh Ekstrak Kayu Manis Terhadap Kadar Glukosa Darah Tikus. Damianus Journal of Medicine, Vol. 10 No. 3, 2011, hal. 121-124

20. Fox, Charles dan Kilvert, Anne. Bersahabat dengan Diabetes Tipe 2. Jakarta: Penebar Plus, 2010, hal. 103

21. Chairunnisa, Ririn. Pengaruh Jumlah Pasta Tomat terhadap Penurunan Kadar Glukosa Darah Pada Mencit Diabetes. Jurnal Teknologi Industri Pertanian, 2012.

22. Astuti, Y. D. dan R., Hesti Murwani. Pengaruh Pemberian Jus Tomat Terhadap Kadar Glukosa Darah Pada Prediabetes. Jurnal of Nutrition College, Volume 2, Nomor 1, 2013, hal 111117.

23. Karimi, A. dan Nasab, N. K. Effect of garlic Extract and Citrus aurantifolia (lime) juice and on Blood Glucose level and Activities of aminotransferase Enzymes in streptozotocininduced diabetic rats. World Journal of Pharmaceutical Sciences, 2(8), 2014, p.821827.

24. Vivi. Mengapa Perlu Puasa Sebelum Melakukan Tes Darah. [serial online] 2016 [cited 17 Juli 2017] Available from : http://klinikdrindrajana.com 